\title{
ANALISIS KESULITAN BELAJAR SISWA DALAM MENYELESAIKAN SOAL LUAS PERMUKAAN DAN VOLUME KUBUS
}

\author{
Rauman Mahmud \\ Program Studi Matematika Universitas Pasifik Morotai \\ Jalan Desa Darame, Kecamatan Morotai Selatan, Morotai, Indonesia \\ e-mail: raumanmahmud1@gmail.com
}

\begin{abstract}
Abstrak
Penelitian ini merupakan penelitian kualitatif deskriptif yang bertujuan untuk mengetahui kesulitan belajar siswa dalam menyelesaikan soal luas permukaan kubus dan volume kubus. Populasi dalam penilitian ini adalah seluruh siswa kelas II SMP Negeri 1 Kabupaten Pulau Morotai sebanyak 84 siswa yang tersebar pada 3 kelas. Sampel dalam penilitian ini adalah siswa II yang berjumlah 24 siswa. Berdasarkan hasil penelitian menunjukkan bahwa pada soal no 1 terdapat 7 siswa atau 30,44\% yang mengalami kesulitan konsep, terdapat 4 siswa atau 21,74\% yang mengalami kesulitan fakta, terdapat 6 siswa atau $26,08 \%$ yang mengalami kesulitan aturan, terdapat 5 siswa atau 2,74\% yang mengalami kesulitan skill, sedang pada soal nomor 2 terdapat 14 siswa atau 60,87\% yang mengalami kesulitan konsep, terdapat 6 siswa atau 26,08\% yang mengalami kesulitan fakta, terdapat 1 siswa atau 4,35\% yang mengalami kesulitan aturan, dan terdapat 2 siswa atau 8,69\% yang mengalami kesulitan skill, kemudian pada soal nomor 3 terdapat 18 siswa atau 78,26\% yang mengalami kesulitan konsep, terdapat 2 siswa atau $8,69 \%$ yang mengalami kesulitan fakta, terdapat 2 siswa atau 8,69\% yang mengalami kesulitan aturan, terdapat 1 siswa atau 4,35\% yang mengalami kesulitan skill, dan pada soal nomor 4, terdapat 11 siswa atau $47,83 \%$ yang mengalami kesulitan konsep, terdapat 7 siswa atau 30,44\% yang mengalami kesulitan fakta, terdapat3 siswa atau 4,35\% yang mengalami kesulitan aturan, terdapat 2 siswa atau 8,69\% yang mengalami kesulitan skill. Kesimpulan yang dapat diambil adalah sebagian besar siswa masih mengalami kesulitan dalam menyelesaikan soal luas permukaan dan volume kubus.
\end{abstract}

Kata Kunci: kesulitan belajar siswa, luas permukaan kubus, volume kubus

\section{ANALYSIS OF STUDENT DIFFICULTY IN SOLVING PROBLEMS SURFACE AREA AND VOLUME OF CUBE.}

\begin{abstract}
This research is a descriptive qualitative study that aims to determine students' learning difficulties in solving surface area of the cube and the volume of cubes problems. The population in this research is as many as 84 students in the second grade of SMP 1 Morotai State Junior High School, spread over 3 classes. The sample in this study was student II, amounting to 24 students. Based on the results of the study, it shows that in question number 1 there are 7 students or $30.44 \%$ who experience conceptual difficulties, there are 4 students or $21.74 \%$ who experience fact difficulties, there are 6 students or $26.08 \%$ who experience difficulties in the rules, there are 5 students or $2.74 \%$ who experience difficulty skills, while in question number 2 there were 14 students or $60.87 \%$ who had difficulty with the concept, there were 6 students or $26.08 \%$ who had difficulty in fact, there were 1 student or $4.35 \%$ who had difficulty in the rules, and there were 2 students or $8,69 \%$ who experience difficulty skills, then in question number 3 there were 18 students or $78.26 \%$ who experienced difficulty in the concept, there were 2 students or $8.69 \%$ who experienced difficulties in fact, there were 2 students or $8.69 \%$ who had difficulty in the rules, there were 1 student or $4,35 \%$ experienced difficulty skills, and in question number 4 , there are 11 students or $47.83 \%$ who experience concept difficulties, there are 7 students or $30.44 \%$ who experience fact difficulties, there are 3 students or $4.35 \%$ who have difficulty in the rules, there are 2 students or $8,69 \%$ experienced difficulty skills. The conclusion that can be taken is that most students still have difficulty in solving problems surface area of the cube and the volume of cubes.
\end{abstract}

Keywords: area of surface and volume of cube, student learning difficulties 


\section{Pendahuluan}

Menurut Arsyad (2002:1) belajar adalah suatu proses kompleks yang terjadi pada setiap orang sepanjang hidupnya. Olenya itu belajar dapat terjadi tanpa mengnal tempat dan waktu. Salah satu pertanda bahwa seseorang itu telah belajar adalah adanya perubahan tingka laku pada diri seseorang yang disebabkan oleh terjadinya perubahan pada tingkat pengetahuan, keterampilan, atau sikapnya. Pada hakekatnya belajar matematika sanggat terkait dengan berpikir matematis. Menurut Hudojo (189: 19), berpikir matematis adalah merumusan suatu himpunan yang telah diketahui atau berhubungan dengan struktur-struktur yang secara mantap terbentuk dari hal-hal yang telah ada sebelumnya.

Kenyatan menunjukkan bahwa dalam proses belajar mengajar masih dijumpai banyak siswa yang masih mengalami kesulitan belajar. Kenyataan inilah yang harus ditangani dan dipecahkan, kesulitan belajar merupakan suatu kondisi dalam proses belajar mengajar yang ditandai dengan hambatan-hambatan tertentu dalam mencapi hasil belajar yang diharapkan. Ahmadi dan Supriyono (2004:77) mengatakan kesulitan belajar yaitu keadan dimana peserta didik tidak dapat belajar sebagaimana mestinya. Jika siswa mengalami kesulitan belajar maka tentunya berkaitan dengan objek belajar.

Menghitung luas permukaan dan volume kubus merupakan salah satu materi penting dalam mempelajari mata pelajaran matematika. Oleh karena itu, sekiranya siswa dapat memahami secara menyeluruh tentang pengaplikasian konsep maupun dapat menyelesaikan berbagai macam persoalan yang berkaitan langsung dengan teori kubus.

Salah satu bentuk kesulitan yang dialami siswa dalam menyelesaikan soal menghitung luas permukaan dan volume kubus adalah siswa yang kurang terampil dalam menentukan volume kubus jika luas alas sebuah kubus diketahui. Sebagai contoh: Luas alas sebuah kubus adalah $64 \mathrm{~cm}^{2}$. tentukan volume kubus tersebut? Jawaban siswa $\mathrm{L}=64 \mathrm{~cm}$ sedangkan rumus volume kubus $=\mathrm{s}^{3}$ berarti $64+64+64=194$. Kesulitan yang dialami siswa untuk menghitung volume kubus pada soal ini, yaitu siswa belum bisa membedakan rusuk dengan luas alas, setelah dimasukan ke dalam rumus siswa tidak bisa melakukan perkalian ulang tetapi yang dilakukan adalah penjumlahan ulang serta satuannya tidak di tulis

\subsection{Rumusan Masalah}

Rumusan masalah dalam penilitian ini adalah bagaimanakah kesulitan belajar siswa kelas II SMP Negeri 1 Kabupaten Pulau Morotai dalam menyelesaikan soal luas permukaan dan volume kubus.

\subsection{Tujuan Penelitian}

Tujuan penilitian ini adalah untuk mengetahui kesulitan belajar siswa kelas II dalam menyelesaikan soal luas permukan dan volume kubus

\section{Metode Penelitian}

\subsection{Jenis Penelitian}

Penelitian ini adalah penelitian kualitatif deskriptif, karna jenis penilitian ini digunakan untuk mengukapkan kesulitan siswa menyelesaikan soal pada materi luas permukaan dan velume kubus.

\subsection{Populasi dan Sampel Penelitian}

Menurut Sugiyono (2007:61), populasi adalah wilayah generalisasi yang terdiri atas objek atau subjek yang mempunyai kualitas dan krakteristik tertentu yang ditetapkan oleh peneliti untuk dipelajari dan kemudian ditarik kesimpulan. Populasi dalam penilitian ini adalah seluruh siswa kelas II SMP Negeri 1 Kabupaten Pulau Morotai sebanyak 84 siswa yang tersebar pada tiga kelas.

Sampel adalah bagian dari jumlah Karakteristik yang dimiliki oleh populasi (Sugiyono 2007:62). Dengan kata lain, sampel adalah bagian dari populasi. Sampel dalam penilitian ini adalah siswa kelas II yang berjumlah 24 siswa.

\subsection{Variabel Penelitian}

Variabel penilitian ini kesulitan dalam menyelesaikan soal luas permukaan dan volume kubus, dengan indikatornya adalah menghitung luas permukaan dan volume kubus.

\subsection{Teknik Pengumpulan Data}

Data dari penelitian dapat diperoleh dengan cara melihat skor yang diperoleh dari kelas yang diteliti melalui tes soal luas permukaan dan volume kubus.

Adapun urutan pengumpulan data dilakukan sebagai berikut:

a. Melakukan observasi untuk menentukan kelas yang dijadikan kelompok subjek penelitian 
b. Memberikan tes kemampuan tentang luas permukaan dan volume kubus

c. Menilai hasil tes yang diperoleh dari kelas yang dijadikan sampel, yaitu kelas II. Selanjutnya data dianalisis dan dipersiapkan untuk membuat laporan penilitian

\subsection{Instrumen Penelitian}

Instrumen yang akan digunakan dalam penelitian ini adalah berbentuk essay berjumlah 4 butir soal. Soal di susun oleh peniliti dengan memperhatikan kompetensi dasar dan indikator materi luas permukaan dan volume kubus serta difalidasi oleh dosen pembimbing.

\subsection{Teknik Analisis Data}

Untuk mengtahui kesulitan siswa dalam menyelesaikan soal luas permukaan dan volume kubus, maka akan dihitung skor yang dicapai oleh siswa tersebut dengan menggunakan rumus TK (tingkat kemampuan).

$$
T K=\frac{\text { Jumlah Skor Yang Diperoleh }}{\text { Skor Total }} \times 100 \%
$$

Selanjutnya, mengklasifikasi tingkat kemampuan siswa ke dalam pedoman acuan patokan (PAP) dengan konversi 5 sebagai berikut:

Tabel 1. Pedoman Acuan Patokan (PAP)

\begin{tabular}{|c|c|c|}
\hline $\begin{array}{c}\text { Taraf } \\
\text { Penguasaan }\end{array}$ & Kualifikasi & $\begin{array}{c}\text { Nilai } \\
\text { Huruf }\end{array}$ \\
\hline $91 \%-100 \%$ & Memuaskan & A \\
$81 \%-90 \%$ & Baik & B \\
$71 \%-80 \%$ & Cukup & C \\
\hline
\end{tabular}

\begin{tabular}{|c|c|c|}
$61 \%-70 \%$ & Kurang & D \\
$<60 \%$ & Gagal & E \\
\hline
\end{tabular}

Thoha (2003:89)

Proses analisis data selanjutnya yaitu dengan menghitung presentase dari tiap jenis kesalahan yang dilakukan oleh setiap siswa dalam menyelesaikan soal di setiap nomor digunakan rumus sebagai berikut :

$$
\begin{aligned}
& \text { Presentase } \\
& =\frac{\text { Jumlah tiap frekuensi disetiap nomor soal }}{\text { Jumlah sampel }} \times 100 \%
\end{aligned}
$$

\section{Hasil dan Pembahasan}

Penilitian ini dilaksanakan di SMP Negeri 1 Kabupaten pulau morotai selama 7 hari melalui tes tertulis tentang kesulitan siswa dalam menyelesaikan soal menghitung luas permukaan dan Volume kubus. Jumlah sampel pada penilitian ini adalah 24 siswa dengan demikin 24 siswa yang dapat diteliti kesulitannya. Hasil yang diperoleh dari sampel ini adalah 23 siswa,dengan demikian 24 siswa yang dapat diteliti kesulitannya. Hasil yang diperoleh dari sampel dijelaskan sebagai berikut :

Dari 24 siswa terdapat 1 siswa 4,35\% yang hasilnya baik karena memperoleh skor total 36 , sehingga dalam penilitian ini adalah 23 siswa yang mengalami kesulitan. Adapun kesulitan yang dialami 23 dari 24 siswa dapat diuraikan sebagai berikut :

Tabel 2. Kesulitan Siswa Dalam Menyelesaikan Soal Luas Permukaan dan Volume Kubus

\begin{tabular}{|c|c|c|c|c|c|c|c|c|}
\hline \multirow{2}{*}{$\begin{array}{c}\text { No } \\
\text { soal }\end{array}$} & \multicolumn{10}{|c|}{ Jenis kesulitan } \\
\cline { 2 - 9 } & Konsep & $\%$ & Fakta & $\%$ & Aturan & $\%$ & Skill & $\%$ \\
\hline 1 & 7 & 30,44 & 5 & 21,74 & 6 & 26,08 & 5 & 2,74 \\
2 & 14 & 60,87 & 6 & 26,08 & 1 & 4,35 & 2 & 8,69 \\
3 & 18 & 78,26 & 2 & 8,69 & 2 & 8,69 & 1 & 4,35 \\
4 & 11 & 47,83 & 7 & 30,44 & 3 & 4,35 & 2 & 8,69 \\
\hline
\end{tabular}

Berdasarkan tabel di atas dapat dilihat sebagai berikut :

a. Untuk soal nomor 1 terdapat 7 siswa yang mengalami kesulitan konsep, 5 siswa mengalami kesulitan fakta, 6 siswa mengalami kesulitan aturan dan 5 siswa mengalami kesulitan skil

b. Untuk soal nomor 2 terdapat 14 siswa yang mengalami kesulitan konsep, 6 siswa mengalami kesulitan fakta, 1 siswa mengalami kesulitan aturan, dan 2 siswa mengalami kesulitan skill. c. Untuk soal nomor 3 terdapat 18 siswa yang mengalami kesulitan konsep, 2 siswa mengalami kesulitan fakta, 2 siswa mengalami kesulitan aturan dan 1 siswa mengalami kesulitan skil.

d. Untuk soal nomor 4 terdapat 11 siswa yang mengalami kesulitan konsep, 7 siswa mengalami kesulitan fakta, 3 siswa mengalami kesulitan aturan dan 2 siswa mengalami kesulitan skil.

Tabel 2. Jumlah dan Jenis Kesulitan Siswa 


\begin{tabular}{|c|c|c|c|c|}
\hline \multirow{2}{*}{$\begin{array}{c}\text { No } \\
\text { Soal }\end{array}$} & \multicolumn{4}{|c|}{ Jenis kesulitan } \\
\cline { 2 - 5 } & Konsep & Fakta & Aturan & Skill \\
\hline 1 & 7 & 5 & 6 & 5 \\
2 & 14 & 6 & 1 & 2 \\
3 & 18 & 2 & 2 & 1 \\
4 & 11 & 7 & 3 & 2 \\
Jumlah & 50 & 20 & 12 & 10 \\
\hline
\end{tabular}

Mengacu pada hasil tes siswa sebanyak 24 orang dapat dijelaskan sebagi berikut :

a. Kesulitan siswa dalam menyelesaikan soal nomor 1

i. Terdapat 7 siswa atau $30,44 \%$ yang kesulitan dalam menyelesaikan soal tidak sesuai dengan langkah-langkah, sebab siswa tidak memahami aturan perkalian bilangan berpangkat, kesulitan ini adalah kesulitan konsep.

$$
\begin{aligned}
& L=6 s^{2}=6 \times 11^{2} \\
& =66^{2}=4356 \mathrm{~cm}^{2}
\end{aligned}
$$

ii. Terdapat 4 siswa atau $21,74 \%$ kesulitannya dalam penulisan simbol positif, kesulitan ini adalah kesulitan fakta : siswa mengerjakan

$$
\begin{aligned}
L & =6 s^{2}=6 \times 11 \times 11 \\
& =6+121=127
\end{aligned}
$$

iii. Terdapat 6 siswa atau $26,08 \%$ yang kesulitannya salah menggunakan rumus, kesulitan ini adalah kesulitan aturan, seiswa mengerjakan

$$
\begin{aligned}
L= & 6 s^{3}=6 \times 11 \times 11 \times 11 \\
= & 66+121=7986
\end{aligned}
$$

iv. Terdapat 5 siswa atau $2,74 \%$ yang mengalami kesulitan pada jawaban akhir, kesulitan ini adalah kesulitan skill. Siswa mengerjakan.

$$
\begin{aligned}
L & =6 s^{2}=6 \times 11 \times 11 \\
& =6+121=626
\end{aligned}
$$

b. Kesulitan siswa dalam menyelesaikan soal nomor 2

i. Terdapat 14 siswa atau $60,87 \%$ yang mengalami kesulitan yaitu siswa yang mengalikan langsung tidak mencari nilai rusuk kesulitan ini adalah kesulitan konsep. Siswa mengerjakan

$$
L=6 s^{2}=6 \times 294=1764
$$

ii. Terdapat 6 siswa atau 26,08\% yang mengalami kesulitan pada penulisan satuan kesulitan ini adalah kesulitan fakta. Siswa mengerjakan

$$
V=s^{2}=7 \times 7 \times 7=353
$$

iii. Terdapat 1 siswa atau $4,35 \%$ yang mengalami kesulitan pada rumus kesulitan ini adalah kesulitan aturan. Siswa mengerjakan.

$$
L=s^{2}=294^{3}=86436 \mathrm{~cm}^{3}
$$

iv. Terdapat 2 siswa atau $8,69 \%$ yang mengalami kesulitan pada jawaban akhir kesulitan ini adalah kesulitan skill. Siswa mengerjakan.

$$
V=s^{3}=7 \times 7 \times 7=243 \mathrm{~cm}
$$

c. Kesulitan siswa dalam menyelesaikan soal nomor 3

i. Terdapat 18 siswa atau $78,26 \%$ yang kesulitannya tidak mencari nilai rusuk tetapi langsung di selesaikan dengan menggunakan rumus luas permukaan kubus. kesulita ini adalah kesulitan konsep. Siswa mengerjakan.

$$
L=6 s^{2}=6 \times 32=6144 \mathrm{~cm}
$$

ii. Terdapat 2 siswa atau $8,69 \%$ yang mengalami kesulitan dalam menulis simbol negatif $(-)$ dan positif (+) kesulitan ini adalah kesulitan fakta. Siswa mengerjakan dari jawaban akhir :

$$
L=6 \mathrm{~s}^{2}=6 \times 32^{2}=130 \mathrm{~cm}
$$

iii. Terdapat 2 siswa atau $8,69 \%$ yang kesulitannya dalam menggunakan rumus. Kesulitan ini adalah kesulitan aturan. Siswa mengerjakan

$$
L=s^{2}=294^{2}=1024 \mathrm{~cm}
$$

iv. Terdapat 1 siwa atau $4,35 \%$ dari 23 siswa yang kesulitan pada jawaban akhir. Kesulitan ini adalah kesulitan skill.

$$
\begin{aligned}
L=6 s^{2}=6 & \times 8^{2}=6 \times 64 \\
& =348 \mathrm{~cm}
\end{aligned}
$$

d. Kesulitan siswa dalam menyelesaikan soal nomor 4

i. Terdapat 11 siswa atau $47,83 \%$ yang kesulitannya dalam mencari nilai rususk. Kesulitan ini adalah kesulitan konsep siswa mengerjakan

$$
V=s^{2}=81^{3}=531441 \mathrm{~cm}
$$

ii. Terdapat 7 siswa atau $30,44 \%$ yang kesulitannya pada satuannya. Kesulitan ini adalah kesulitan fakta. Siswa mengerjakan dari jawaban akhir :

$$
V=s^{3}=9^{3}=729 \mathrm{~cm}
$$

iii. Terdapat 3 siswa atau $4,35 \%$ yang kesulitanya dalam menggunakan rumus. Kesulitan ini adalah kesulitan aturan. Siswa mengerjakan

$$
\begin{aligned}
L_{\text {alas }}=6 s^{2}= & 6 \times 81^{2}=6 \times 6561 \\
= & 39366 \mathrm{~cm}
\end{aligned}
$$

iv. Terdapat 2 siswa atau $8,69 \%$ yang kesulitannya pada jawaban akhir,kesulitan ini adalah kesulitan skill. Siswa mengerjakan dari jawaban akhir.

$$
V=s^{3}=9^{3}=739 \mathrm{~cm}^{3}
$$




\section{Kesimpulan}

Dari pembahasan di atas, maka dapat diambil kesimpulan bahwa secara keseluruhan siswa kelas II SMP Negeri 1 Kabupaten Pulau Morotai dalam menyelesaikan soal luas permukaan dan volume kubus, terdapat 15 dari 24 siswa $(65,22 \%)$ yang mengalami kesulitan skill. Terdapat 18 dari 24 siswa $(78,26 \%)$ mengalami kesulitan konsep. Hal ini menunjukkan bahwa secara kesuluruhan siswa masih mengalami kesulitan konsep, 5 dari 24 siswa $(21,74 \%)$ mengalami kesulitan aturan,dan 6 dari 24 siswa $(26,09 \%)$ mengalami kesulitan fakta.

\section{Daftar Pustaka}

Arsyad, Azhar. 2002. Media Pembelajaran, Ed. I,Cet. 3, Raja Grafindo Presada, Jakarta

Ahmadi dan Supriyono 2004. Psikologi Belajar. Rineka Cipta: jakarta

Hamalik, Oemar.1983. Metode Mangajar dan kesulitan - kesulitan Belajar : Bandung Tarsito

Sugiyono, 2007 Statistik Untuk Penelitian. Alfabeta. Bandung

Thoha, M.C. 2003. Teknik Evaluasi Pendidikan. Jakarta : Raja Grafindo Pertsada 
